\title{
6
}

\section{Of Mothers, Adoption and Orphans: The Significance of Relatedness in a Remote Aboriginal Community}

\section{Victoria Katherine Burbank}

\section{Introduction: Mothers}

One day, in 1978, I accompanied a woman I call Lily on a trip that took us from the remote Aboriginal community of Numbulwar up the coast to an outstation for a few days of respite from the demands and distractions of settlement life. We were accompanied by three of Lily's children and one of her sister's sons, all of whom were of primary-school age. I was driving, Lily sat beside me and the children were in the back of the Land Rover. Her sister's son was an active child and on the long and rough trip to the outstation appeared to annoy his 'brothers', one of whom may have smacked him. In any event, the sister's son began to cry and was rebuked, perhaps by his attacker, with, 'Stop crying, your mummy isn't here', clearly referring to the boy's biological mother who had remained in the township. Now according to the kinship nomenclature employed at Numbulwar, particularly that of the Indigenous language, his 'mother' was there, for as is the case with Aboriginal kin terminology more generally, there is an equation of same-sex siblings; hence all the children with us that day called both Lily and her sister, 'mother'. Still, this child's 'brothers' 
noted a distinction between their mother and his, and by extension, we may presume, between their cousin and themselves. Marshall Sahlins has decried the fact that 'kinship has too often been analysed from the way it is lived and learned by individuals' (2013: 66), but I do just that. Assuming that the locus of cultures is to be found in mind, rather than floating freely in a social ether (D'Andrade 1995; Shore 1996), the way something is 'lived and learned by individuals' is often just what anthropologists should be studying. Admittedly, as Melford Spiro pointed out with reference to a confusion between 'cultural conceptions of the person' and 'the actors' conceptions of the self' (1993: 117), we should not assume that an encoded system of kin terminology is isomorphic with the way that kinship is 'lived and learned' but this hardly means that the latter is not worthy of our attention. Lily's sons call her sister 'mother' and her son 'brother', but clearly they do not see Lily's sister in the same way they see their mother, or see her son as exactly like themselves. This, I argue, is a critical kind of observation for understanding sociality in this remote Australian community, and likely elsewhere.

The nature/nurture debate, while quiescent in some anthropological quarters, has been characteristic of what is referred to as the 'new kinship' in which writers, often inspired by David Schneider's (1968) discussion of American kinship, cast it as an entirely cultural construction (Sahlins 2013). Marshall Sahlins provides us with another classic example of this stance, notable both for its persistence and longevity. In a sociobiological treatment of 'Adoption in Oceania', Joan Silk (1980) may have been the first in these debates to challenge his claim, that 'kinship is a unique characteristic of human society, distinguished precisely by its freedom from natural relationships' (Sahlins 1976: 58; in Silk 1980: 800). Some 30 years later he continues to provide us with examples of the dichotomisations of a topic that, at least, some now think is better treated in an integrative manner. Although he pays attention to human psychology, he continues to sever 'meaningful social endowment' from 'mere physiological substance'; insisting that kinship is 'a thoroughly symbolic-cum-cultural phenomenon' (Sahlins 2013: 65-66). In so doing, Sahlins ignores what a number of anthropologists increasingly see as vital components of cultural experience, what some describe as our 'biogenetic heritage': the potentials and constraints of our bodies and brains arising from our evolutionary history (e.g. Downey and Lende 2012). In contrast to the 'new kinship', the 'extensionist' position in kinship studies calls for just such treatment. Warren Shapiro (e.g. 2005, 2009, 2012) has long 
and energetically defended extensionism, an approach which assumes that people in general are often, if not always, acute observers of human activity, including reproductive activity, and that a kinship term such as 'mother' derives its meaning from the observation that a specific woman gives birth to a specific child. While these terms may be applied to others, in the case of 'mother', say, to her sisters, in some cases, it is recognised that in its extended application the entirety of its original meaning no longer applies. In this paper, I join Shapiro's, and Silk's, efforts by drawing upon the thinking of several writers who have attempted to incorporate inclusive fitness theory into kinship exegesis, thus integrating the biogenetic with the social and cultural. It will soon become clear that when viewed from an evolutionary perspective, Harold Scheffler's defence of the 'kinship terms and extensions' (1978: 21) interpretation of Aboriginal kin classification, his ideas about polysemy, the focality of some kin, like fathers and mothers, and the extension of labels for them to less focal others makes perfect sense, at least in Aboriginal Australia. It also illuminates some of the behaviour associated with what I have labelled adoption/fosterage in the remote Aboriginal community of Numbulwar.

\section{Inclusive fitness and cultural experience}

William Hamilton's (1964a, 1964b) theory of inclusive fitness, or kin selection, as it is sometimes known, has found a place at the centre of contemporary evolutionary thinking. 'Fitness' is the number of copies of an individual's genes, relative to others of its kind that are passed on to the next generation. The idea that organisms increase their fitness insofar as they are able to increase that of their close kin, given a cost/benefit advantage to ego, helps us understand a great deal about human sociality. A brother, say, who instead of having children himself, provides the additional calories that his nieces and nephews need to survive, grow and reproduce, may well end up with greater fitness than he would were he to bring his own offspring into a world that could not support them, or if he were to contribute to the children of an unrelated individual. In discussions of inclusive fitness it is usually assumed that the probability of sharing alleles (a variant of a gene) with a parent or sibling is 0.5 or 50 per cent. The coefficient of relatedness between half siblings is 25 per cent, as is that of aunt/uncle and nephew/niece, grandparent/grandchild. That of first cousins is only 12.5 per cent (Buller 2005: 351-52; Daly and Wilson 1983: 28-31). When Lily's sister's son was crying, he may well have been 
appealing to her for help in a 'fraternal' rivalry, whatever that might have been. Crying can be a form of demanding, to which adults may choose to respond, or not. It seems a fair assumption that the sister's son's behaviour was seen by his 'brother' as an attempt to gain his mother's allegiance and hence an advantage over her own son. The rebuke, 'your mummy isn't here', can be read as a signal both to his rival and to his mother that her sister's child was, in relatedness terms, less worthy of her attention than his opponents, her own genetic offspring.

The idea of inclusiveness fitness, like much of evolutionary theory, does not require organisms to act consciously in terms of its principles, only that their behaviour contributes to their greater relative fitness. Just what mechanisms may be at play and just what their ontological status may be has been a focus of evolutionary psychology, and considerable debate, for several decades (e.g. Buller 2005; Pinker 2003). Ideas about evolved psychological potentials, however, do not exclude a role for culture. On the contrary, increasingly culture is understood to have been the critical component of the environment in which our bodies and brains originated and hence an intrinsic part of almost anything we are and do (e.g. Lende and Downey 2012; Richerson and Boyd 2005; Tomasello 1999). The tricky part is understanding how biology and culture work together in human experience.

Maurice Bloch and Dan Sperber (2002) posit a scenario in which speciesspecific, genetically inherited, and hence universal, 'dispositions' direct our interest and attention to the kind of information we once needed, and perhaps still need, in the evolutionary game of reproductive success. This may occur even where historical processes have created settings where such information is neither emphasised nor valued. These dispositions do not create cultural representations, though they may contribute to their creation, but rather bias the possibility that such representations may stabilise in a cultural community. For example, inclusive fitness theory predicts that, individuals would tend to show interest in evidence of relatedness, whether or not culturally codified' (Bloch and Sperber 2002: 732). Acting as attractors these dispositions create relative stability and limited variability in spite of processes-environmental and historicalthat constantly introduce variation and change into any cultural system (ibid.: 727-28). We might then understand whatever neuropsychological mechanisms exist to implement kin selection strategies as the attractors of kin-based behaviour in the midst of stochastic variations introduced in historical and environmental processes. 
The distinction between 'your mother' and the unspoken, though logically implied, 'my mother', suggests just such 'interest in evidence of relatedness' (Bloch and Sperber 2002: 732). Wubuy is the dominant Indigenous language of Numbulwar, though most people there today speak an English-based creole, called 'Kriol' by its speakers. In the Wubuy kinship terminology, same-sex siblings are equated linguistically as are their children. That is, the children of two sisters would call both of them, 'mother' and the children of both women, 'sibling'. However, while terms of address do not include words for distinguishing a biological mother from a classificatory one, the linguist Jeffrey Heath has made note of the word, ardiya. It is 'not morphologically a kin term', he says, but is used to designate an 'expecting mother' and distinguish a woman as the 'true (biological) mother (of a particular child)' (1982: 177). ${ }^{1}$ Furthermore, 'expressions like mana-da:n-jinyung "of the guts"' (i.e. of the womb) can be used in conjunction with the word for "mother" or "MoBr" to specify "actual mother" or "full brother of actual mother" (ibid.: 330). Shapiro has observed similar expressions in northeast Arnhem Land (1979: 8). In Wubuy only two terms, rrigang and bibi, are used for $\mathrm{M}, \mathrm{MZ}, \mathrm{MB}$, MBD, MBS and MBSS in an Omaha-type skewing of the terminology. However, Kriol terms are used by many to distinguish $\mathrm{M}, \mathrm{MZ}$ and $\mathrm{MB}$ from the remainder of these Wubuy categories. The former are designated as 'mummy' and 'uncle', the latter as the interchangeable terms 'barnga' or 'cuz'. While this may be an attempt to bring the local kin terminology more into accord with the English system-for Numbulwar is an intercultural environment and Aboriginal people often try to communicate in ways that English speaking outsiders will understand—we might note that the distinctions clearly reflect diminishing coefficients of relatedness: 50 per cent to 25 per cent for 'mummy' and 'uncle', but only 12.5 per cent to 3.13 per cent for 'barnga' and 'cuz' and that their use may well represent a welcome means of expressing an intuitive sense of these differences.

Given kin selection as a force in human history, it is not surprising that humans appear to have capacities for kin recognition (e.g. DeBruine et al. 2009; Lieberman, Tooby and Cosmides 2007a; Porter 1991), perhaps particularly those that enable phenotypic matching, the ability to

1 Heath also points out that Wubuy phrases that may be translated as 'to beget, sire, be the father of' or 'to give birth to, bear, be the mother of' 'are freely extendable to opposite-sex siblings of the designated parent; thus a woman can say ... "I begat him" of her brother's child 'and a man can say ... "I bore him" of his sister's child. The mother's clan or its territorial centre can also be said to have "borne” a given person' (1982: 330). 
recognise kin on the basis of similarity, whether that of appearance, smell or sound. This is something that the people of Numbulwar believe they can do, on occasion with substantial consequences:

Sometimes a family here don't like [an unmarried] girl in the first place. But when they get pregnant and they have that little baby and when they see that baby is true for their son, that baby has their son's face, they won't growl at that girl. They will feel ashamed [and let] them marry (Teenage girl, in Burbank 1988: 109).

Children, say women at Numbulwar, take their mothers' and fathers' bodies. When a child is a foetus both mother and father grow thin before they grow fat:

The child takes mother and father's body and makes them weak. Like Margira and his wife. They are strong because they don't have any children. ${ }^{2}$ They are a bit old but still strong, not like Margira's brother who has children. He is weak (Woman speaking, unpublished fieldnotes, 1978).

In particular, a man is said to give his children his face and his foot. Lest readers be confused by the word 'foot', let me explain that as far as the people of Numbulwar are concerned, feet mark the individuality of a person much as does a face. The footprints that each person leaves are regarded as distinctive and older people, at least, can identify the prints of close kin, if not of all familiar individuals. If a woman who is known to have a lover bears a child who does not look like her husband, its paternity may be suspect. Once, when I was accompanied in the field by my son and husband, a visiting neighbour emphatically declared that their feet were identical, a compliment, no doubt, on my marital fidelity (Daly and Wilson 1982). All of this is to reiterate that the people of Numbulwar appear to believe they have the means of distinguishing among actual and classificatory parents, children, siblings and other kin. They also, I argue, have the motivation to do so. The distinctions that people make between 'close family' and others are, not surprisingly, reflected in behaviour. For example, only 'close relations' would take part in each other's fights; should an outsider attempt to do so, he or she might well be attacked (Burbank 1994: 76). And as with linguistic distinctions, these are not a peculiarity of Numbulwar. A child socialisation practice at Yuendumu provides an example from another remote Aboriginal community. There, adults

2 The word 'strong' is more often used in the sense of selfish or unwilling, as in 'He is strong, he can't let them use that tractor' and is opposed to 'kind', giving or kind. 
regularly engage in lani-mani, frightening toddlers with the explicit intent of warning them of dangers such as bullocks and snakes. According to the ethnographer, 'One only conducts lani-mani session with one's own children ... People say, "You gotta be close to that kid, it wouldn't be right to scare other people's children"' (Musharbash 2016: 175).

\section{Adoption/fostering}

The ways in which people at Numbulwar both embrace a greater circle of kin than is typical in the western world, yet distinguish among those kin, and the fact that both the embrace and discrimination can be linked to coefficients of relatedness, helps us understand some of the practices and ideas associated with adoption/fostering in such a community. As neither 'adoption' nor 'fosterage' provide an adequate translation of the kind of alloparental care I discuss (see Goody 1971), both terms are used interchangeably to indicate that I am talking about practices that resemble both western arrangements.

If a woman has no babies and if another has plenty and if that woman with none likes one, she is going to ask, 'Could you give me one that I could look after?' The woman with plenty can't say no because she has too many [a lot]. That stepmother will keep that little girl for her own, and when she is big that woman will do all the talking for her marriage or if there is trouble ... If someone asks the mother [about the girl's marriage], she will say, 'Don't' ask me, ask her stepmother'. And if the girl makes trouble the stepmother will pay for it, like broken windows. If the mother goes [to] another place the stepmother will keep the girl with her. They give little boys too (Burbank 1980: 52). ${ }^{3}$

Alloparental care is a practice both of past and contemporary local scenes. A residence survey of the 800 or so people living at Numbulwar in 2003 indicates that there were at least 18 children under the age of 18 who were living apart from both of their biological parents, while life history accounts of adults sometime include mention that a child was raised by someone other than his or her mother and/or father. Children have been given to others when their mother dies or when a woman asks a kinswoman for one of hers, sometimes because she has none of her own. On more than one occasion, when a child was thought to be at risk due

3 I believe the word 'stepmother' used in this account was only for my benefit. It is not a word generally used to describe women looking after adopted/fostered children. 
to neglect or abuse, a kinswoman has stepped in and taken the child to raise as her own, at least for as long as necessary. Often a close genetic relationship, a coefficient of at least 25 per cent, can be traced between the carer and the child. In all cases of which I am aware, fostered children continue to be regarded as the child of their biological parents; they call their foster parents by the kin terms they would have used should they have stayed with their birth mothers.

Along with the responsibilities of caring for a fostered child come some rewards; there are both observable and less tangible benefits to alloparenting. As the speaker above indicates, in the days when girls were bestowed in marriage, a foster mother would have the right to make the bestowal. ${ }^{4}$ Today, women who foster infants and toddlers can anticipate 'respect' from them in future years. While 'respect' is a new word in the local idiom, people appear to use it to mean the help and support due to a person, especially a family member. Once, for example, a woman complained to me that a man she had once fostered as a child was not taking her side in an argument: 'They gave him to me' when he was little, after his mother died, 'I was looking after him, he should respect me' (2004).

Foster children can be of assistance to the fosterer, especially perhaps, if they are girls (see Hamilton 1981). A foster grandmother, for example, who had been looking after an adolescent girl until she moved on to live with other kin, told me how she had been talking to her other granddaughters: 'Because [my foster child is] gone now, you are going to help me, wash my clothes, cook' (2004). And foster parents may receive government 'child cheques', that is, Child Benefit money.

There are, of course, also costs to fostering children. Numbulwar, like other remote communities in Australia, is a poor community. There are few if any people living there who do not sometimes lack for money and the essentials it can buy. Perhaps even more critically, there is social want as well. David McKnight's (1986) 'relational density', a measure of the number of relationships characterised by kin-like rights and duties, is useful for visualising daily life at Numbulwar: so many relationships of material and emotional significance; so many people with so many needs. Looking at any kindred there, one can see, along with familial affection and

4 This is assuming that the child had not been assigned a husband via mother-in-law bestowal. On mother-in-law bestowal, see Shapiro (1970). 
succour, myriad forms of trauma and disadvantage: premature mortality, mental and physical illness, disability, substance abuse, domestic violence, hunger, truancy, vandalism, unemployment, debt-the list could go on. As the speaker above indicates, along with other duties towards a child, fosterers may be held responsible for their misbehaviour, a responsibility that might, on occasion, even involve a caretaker in a physical fight (Burbank 1994). In such circumstances, the presence of a foster child might seem to be the straw that breaks the camel's back (see Silk 1990) and we could argue here that the hardship of fostering should disabuse us of the notion that inclusive fitness acts as an attractor in the development of human culture, that it is instead solely based on moral sentiments. Would not a carer be more likely to get more copies of her genes into the next generation if she directed resources exclusively to her own biological children? Why foster another, less related child? Inclusive fitness theory permits another view, however. A broad perspective on human affairs is one of its theoretical strengths (Burnstein, Crandall and Kitayama 1994). Winning the fitness game takes more than just winning a fitness round. And to understand winning even a single round requires knowledge of the context in which a contest takes place. In some circumstances, such as those found at Numbulwar, fostering has the potential to enhance a carer's fitness, and that of her close kin (see also Silk 1980).

There is considerable evidence that being seen as kin can be advantageous (e.g. Burnstein, Crandall and Kitayama 1994). Providing one's own children with additional 'siblings' may thus be a way of increasing one's own fitness and fostering may be a means of doing so (Silk 1980). Looking for 'kin detection mechanisms' among humans, Debra Lieberman, John Tooby and Leda Cosmides (2007a) provide empirical support for the possibility that 'mother/child perinatal association' and 'sibling coresidence' are two means by which humans are able to calculate relatedness. Some of their study subjects had step, adoptive or half siblings. Coresidence, in this case, better than belief in whether or not they were genetic kin, predicted altruism towards a step, half or adopted sibling (Lieberman, Tooby and Cosmides 2007b: 7) suggesting that early and sustained contact can lead both a woman's biological child and her foster child to see each other as 'close' kin, appropriate recipients of help and generosity. As in most of the cases I know, fostered children are already regarded as 'close family', and as such we can anticipate that reciprocal altruism would be reinforced, benefitting both the woman's biological child and the foster child throughout their lifetimes, increasing the reproductive success of 
each. Women then, we might also anticipate, should be motivated to treat foster children as their own, for this again would reinforce the lesson that all the children in her care are 'close family'. Children clearly can learn that unrelated individuals or lesser kin can be like siblings or 'close family'. But we need to ask why humans learn the kinds of things that they do (Bloch and Sperber 2003: 729). Were there not a disposition for kin discrimination, and associated neurobiological mechanisms for implementing it, could we learn to distinguish kin from nonkin, close kin from more distant kin, or care about doing so?

\section{Orphans}

In addition to children fostered as infants or toddlers, there are increasing numbers of older children at Numbulwar today who have lost one or both parents due to divorce, desertion or death. If they are left without adequate kin support, these children may become wangulu.

Wangulu is the word that Aboriginal people at Numbulwar use to translate the English word 'orphans'. But wangulu are not necessarily children without parents. They are people who have no one to look after them. Whether or not one is an orphan is determined by the presence or absence of 'support', a word I first noted hearing from an Aboriginal English speaker in 2005. Adolescents without mobile phones may be described as wangulu. Or, 'when you go anywhere and ask anyone for money and they can't give you, they say wangulu' (Burbank 2011: 151-52). Speaking of the Pintupi of Central Australia, Myers calls orphans yapunta and, much like the use of wangulu, says that yapunta may also signify that an object 'does not belong to anyone' or that 'it has no one holding or looking after it' (Myers 1988: 55). In the township of Borroloola, roughly 209 kilometres down the coast from Numbulwar, some adolescent suicide victims are described as 'poddy' girls or boys, that is, as young people who were neglected by their families, often because of parental substance abuse (McMullen 2014). Sue McMullen observes that the term 'poddy' appears to have been derived from " "poddy calf", a calf with no mother' (ibid.: 113). With long experience of the cattle stations in the surrounding countryside, Aboriginal people at Borroloola might well be familiar with this term. Of the Pintupi yapunta, Fred Myers has said that such individuals manifest 'an anger that is not appeased' and are more likely to become 'the most active petrol sniffing children' (1986: 178). 
Maggie Brady (1992: 75) has observed something similar of adolescents in the Western Desert, though it is not clear if these are children without parents or children with parents who 'don't worry' about them (McMullen 2014: 113). I have found a somewhat more complicated picture of people who might be considered wangulu at Numbulwar: they may be petrol sniffers, but they may also be those who are relatively 'successful' according to western standards (Burbank 2006: 17, 11).

More than one observer of Aboriginal Australia has noted that the highly responsive and nurturing kind of infant care characteristic of their communities is followed by a period of lessened parental engagement expressed in an expectation that more mature children who are able to ask for something will do so. Subsequently, children are largely left to their own devices when it comes to satisfying their needs, including their need for food (see Brady 1992; Hamilton 1981; Myers 1986). Crying, as mentioned above, may be one means of asking for something, an action that enables an adult to decide whether or not to respond. Thus children who are fostered at a more advanced age may be less likely to receive the same degree of nurturing that a younger child receives. Between 2003 and 2005, I observed several children, both male and female, who appeared to be in just such a situation. For example, I repeatedly saw them wearing the same dirty clothing in contrast to the sometimes new and usually clean attire of their 'siblings'. This relative neglect may not simply be a function of an adult's awareness of a fostered child's more distant kin position, however. It may also be due to the behaviour of the children they now live amongst. Once, for example, I overheard two teenage 'sisters' reproaching a third, younger, cousin who was being looked after by their grandmother. All three wanted a 'cold drink' but the money they asked for was not forthcoming. The fostered child was then told by her cousins that she was 'a young girl' now, an adolescent, and should be doing work for her fosterer, not asking her for money (unpublished fieldnotes, 2003).

What may be of particular significance in this case is the fact that the fostered adolescent's father was from a distant community, and hence probably regarded, at best, as a distant sort of kin. As the theory of inclusive fitness goes, kin-based cooperation can be expected to reflect coefficients of relatedness. Like Eric Smith, those who work with evolutionary theory generally assume that 'kinship ... is a key organizing principle in all societies' but that 'coefficients of relatedness drop off rapidly outside a narrow orbit of close kin' (2003: 422). Stuart West, Claire El Mouden and Andy Gardner, however, have taken issue with the latter supposition, 
observing that we assume, sometimes mistakenly, that 'relatedness can only be high between close family relatives' (2011: 243). They point out that the 'well-known approximations of relatedness', such as I have used above, are based on an assumption that a population is large and genetically diverse. We need to ask if this is indeed the case for a community such as Numbulwar, or if it is better described as a 'viscous population', one which is relatively sedentary, with little in or out migration. If the latter is the case, then 'relatedness between group members can be relatively high because it will tend to increase the genetic similarity between interacting individuals' (ibid.: 243). Although genealogies show some community exogamy occurring over the last four generations, Numbulwar is a small and largely stable population, numbering between only about 400 and 800 people over the 30 years I have been working there. Given polygynous marriage, much of it sororal (Chisholm and Burbank 1991), and the leverate, practised until only a few generations ago, we might be right to assume a relatively high degree of relatedness as a characteristic of the community as a whole. ${ }^{5}$ Thus the extension of focality to seemingly more distant genetic relatives may well make sense as much in fitness terms as in terms of social solidarity (Park, Schaller and Van Vugt 2008; Shapiro 2005). At the same time, someone like the adolescent cousin, with a parent from a distant population, may actually be less genetically related to her cousins at Numbulwar, and to her mother and grandmother, than she might have been had her father been a local man.

\section{Close family}

As should be apparent by now, people at Numbulwar take care to distinguish 'close family' from other kin and treat them differently, as a rule. A segment of people in every egocentric social environment at Numbulwar is described as 'close' or 'full relations'. The totality of these may be described as a personal kindred (Shapiro 1979: 57). One of the criteria for recognising someone as a 'full relation', or 'family' is the recognition of a genealogical link such as sharing a grandparent whether

5 I have undertaken fieldwork at Numbulwar on eight occasions between 1977 and 2007. The last series of trips took place between 2003 and 2007. White and Parsons' study of genetic differentiation in Arnhem Land 'confirmed the relative isolation of the extreme Arnhem Land tribes' (1973: 5). Although the Nunggubuyu were not included in this study, it is nevertheless suggestive in this context. A study in which the Nunggubuyu were included found notable genetic differentiation between groups in Arnhem Land and elsewhere in Australia (see Balakrishnan, Sanghvi and Kirk (1975). 
MM, FM, FF or MF. All of the people in one's 'clan' are 'family' as are the people in one's mother's clan: 'My family is Nunggargalung [speaker's mother's "clan"], like mother and uncle, family. My [mother's mother] and [mother's father]. ${ }^{6}$ They feeling flesh. We say, "We all one race" (1978). Someone may, however, be regarded as a 'full relation' because of a totemic connection: ' $\mathrm{He}$ is full relation to me because of that dreamtime story. Goanna comes from his country. I am goanna too, because goanna went from Wurindi to Hodgson Downs' (unpublished fieldnotes, 1978). The term 'close', however, may be reserved for people with a genealogical link; 'close' was explained to me with reference to a shared ancestor, as in, they are 'close family' because they are 'one granny'. And this in turn, as the spatial metaphor would suggest (Lakoff and Johnson 1999), is associated by some, at least, with greater cooperation and intimacy: 'We are same grandfather and grandmother, we like each other, we can share' (unpublished fieldnotes, 2005).

Sometimes, however, even 'close' family may not be close enough. The harsh language directed to the fostered adolescent from her older cousins, might be interpreted simply as older children directing a younger one to do the kinds of things expected of her (see Hamilton 1981). However, the teenagers' words did not strike me as this kind of instruction. They struck me as harassment, a mildly aggressive form of competition. I have seen too many contests between full siblings to say that competition is restricted to those who share smaller coefficients of relatedness. Nevertheless, it may be that children are the most active agents of kin differentiation when it comes to others who are not their parents' own. The fostered girl was the teenage sisters' 'close relation', but she may not, by virtue of her father's genetic contribution, have been as close to her cousins as they were to each other, and they, in turn, to her fosterer, for they were the children of two local brothers with spouses from 'clans' long associated with Numbulwar. The question, however, is how might this discrimination be made? Clearly the teens knew that the adolescent's father came from a distant community. But they also knew that the three of them shared grandparents. What form of information should take precedence? And how might this occur? Thinking again about mother/child perinatal association and sibling coresidence (Lieberman, Tooby and Cosmides 2007a), we might ask how much time the adolescent and her mother spent at Numbulwar during

6 'Clan' is what most people at Numbulwar call named groups associated with specific 'country' via patrifiliation, at least in conversation with whitefellas. 
her early years. These authors have observed that 'when MPA [mother/ child perinatal association] is absent and coresidence is used as a cue to relatedness' between '14-18 years of coresidence duration' is required to have the same effect on individuals who have not witnessed mother/ child perinatal association (ibid.: 1). Coresidence, however, as mentioned above, can have powerful effects in creating a kin-like relationship between unrelated people (ibid.: 7). To judge by the frequency of the adolescent's visits to her father's community between 2003 and 2007, it is probable that the two teenage 'sisters' spent much more time together than they spent with their adolescent cousin. The children of siblings are often companions throughout their early years, as was the case with Lily's and her sister's sons, whereas the adolescent cousin was, most likely, only an occasional visitor. By the same token, observation of her perinatal association with her mother would have been less frequent as well, thus, perhaps, creating the overall impression of the adolescent cousin as less rather than more a family member.

Sibling rivalry is an old theme in the psychological literature on child development. Here in a community where kin terms clearly grounded in the reproductive unit are extended to a more extensive range of people, it should not be surprising to see that 'sibling rivalry' may take place between people who are not genetic siblings. What may be more interesting about this extended rivalry, however, is the way it enables a fosterer to advantage her closest kin, without obviously violating norms of 'caring and sharing' for members of the larger kindred. The teenagers' actions obscured the fosterer's reluctance to provide money for 'cold drinks', enabling her, perhaps, to put her limited resources to better purpose. Silk has observed that when children are unrelated to their adoptive parents 'the addition of a child is always costly for the existing children' (1980: 802). At least some children at Numbulwar seem able to recognise this as the case when children are less related to the carer, and to themselves, if not in the language of fitness, then in the economic language of scarce resources. When children who are more related to a carer compete with children who are less so, they may be acting not only in their own but also in the caregiver's reproductive interests.

Numbulwar is an environment in which even the unity of 'close family' might be disrupted for it is fairly described as an environment characterised by want. Yet its Indigenous inhabitants are surrounded by 'whitefella' wealth, much of which appears to be extremely attractive, whether this be a mobile phone or a 'cold drink' (Burbank 2011). For children especially, 
the inadequate incomes of their households and the dearth of adult carers, due to high rates of premature morbidity and mortality, create a scarcity of necessary and desired goods and adults they can turn to in times of need. In these circumstance it would not be surprising if the teenage 'sisters' saw themselves in competition with their adolescent cousin for essential resources. This observation and others like it suggests that it may be children rather than adults who are the primary agents of kin discrimination when a foster child is in the family.

\section{Conclusion}

In what may be a 'viscous population', the fact that kin terms for nuclear family members are often extended to others suggests an intuitive understanding that many if not most individuals in the community are relatively close, genetically speaking. Nevertheless, Aboriginal people, at least at Numbulwar, take pains to distinguish actual from classificatory kin, and 'close family', or just 'family', from others. These distinctions reflect both biological and sociocultural realities. In an environment of scarcity, competition is to be expected and, especially in cases where such competition may be critical not simply for quality of life, but for life itself, coefficients of relatedness are pertinent (see Burnstein, Crandall and Kitayama 1994). Just how relatedness is determined in this community can only be extrapolated from the experimental literature. Mother/ child perinatal association and coresidence have a face validity for the situation at Numbulwar. However, the children there complicate a simple understanding of this process. They are not blank slates ready to receive information from something like coresidence without challenge. While addressing the topic of 'parent offspring conflict', several observers of infant behaviour have interpreted night waking as a means of delaying the arrival of the next child, an event which could compromise the health, or even life, of the existing one (Badcock 1990: 74-75). Here we might interpret night waking as an anticipatory form of sibling rivalry, suggesting a readiness to attend to information about threats of resource competition even from the closest of kin. Hence, other aspects of the environment, such as the abundance or lack of food and the presence or absence of nurturing adults may provide equally compelling information to which children are disposed to attend (see Burbank, Senior and McMullen 2015; Nettle, Coyne and Colléony 2013). 
Some years ago, Daly, Wilson and Weghorst (1982) observed that male sexual jealousy was manifest in societies where its expression was contrary to social convention, suggesting that jealousy-like emotions were something more than cultural inventions. Similarly, Bloch and Sperber have postulated that dispositions exist apart from culture, and that when expressed they need not 'be reflected in a cultural norm' (2002: 731). We probably should not speak of a precultural human, however, for culture is so much a part of what we are; our species' heritage is inevitably assimilated into our cultural selves even before birth (Downey and Lende 2012; Richerson and Boyd 2005; Tomasello 1999). We are, however, also animals and hence our biogenetic heritage needs analytic space and attention as an agentic source of our behaviour. In pursuing this route, integrating what we know about biology and psychology into our ethnographic interpretations, I believe we gain a far more detailed understanding of what we currently regard as the cultural aspects of being human. Understanding that kin selection and kin recognition are a part of what we are and what we do enriches our understanding of our own and others' social arrangements just as Scheffler's support and elaboration of the extensionist position has alerted us to the potential significance of kin discrimination in Aboriginal Australian communities.

\section{Acknowledgements}

Fieldwork was supported by the then Australian Institute of Aboriginal Studies, now the Australian Institute of Aboriginal and Torres Strait Islander Studies, Canberra and by an Australian Research Council Discovery Project grant (DP0210203) received with Robert Tonkinson and Myrna Tonkinson in 2001.

\section{References}

Badcock, Christopher. 1990. Oedipus in Evolution: A New Theory of Sex. Oxford: Blackwell.

Balakrishnan, V., L. Sanghvi and R. Kirk. 1975. Genetic Diversity among Australian Aborigines. Canberra: Australian Institute of Aboriginal Studies. 
Berndt, Ronald (ed.). 1970. Australian Aboriginal Anthropology: Modern Studies in the Anthropology of the Australian Aborigines. University of Western Australia, Perth: Australian Institute of Aboriginal Studies.

Bloch, Maurice and Dan Sperber. 2002. 'Kinship and evolved psychological dispositions: The mother's brother controversy reconsidered'. Current Anthropology 43(5): 723-48. doi.org/10.1086/341654

Brady, Maggie. 1992. Heavy Metal: The Social Meaning of Petrol Sniffing in Australia. Canberra: Aboriginal Studies Press.

Buller, David. 2005. Adapting Minds: Evolutionary Psychology and the Persistent Quest for Human Nature. Cambridge, MA: MIT Press.

Burbank, Victoria. 1980. 'Expressions of anger and aggression in an Australian Aboriginal community'. PhD thesis, Rutgers University, New Brunswick, NJ.

—_. 1988. Aboriginal Adolescence: Maidenhood in an Australian Community. New Brunswick, NJ: Rutgers University Press.

—_. 1994. Fighting Women: Anger and Aggression in Aboriginal Australia. Berkeley: University of California Press.

__ 2006. 'From bedtime to on time: why some Aboriginal people don't especially like participating in western institutions'. Anthropological Forum 16(1): 3-20. doi.org/10.1080/00664670600572330

—_. 2011. An Ethnography of Stress: The Social Determinants of Health in Aboriginal Australia. New York: Palgrave Macmillan. doi.org/10.1057/ 9780230117228

Burbank, Victoria, Kate Senior and Sue McMullen. 2015. 'Precocious pregnancy: Sexual conflict and early childbearing in remote Aboriginal Australia. Anthropological Forum 25(3): 243-61. doi.org/10.1080/00 664677.2015.1027657

Burnstein, Eugene, Christian Crandall and Shinobu Kitayama.1994. 'Some neo-Darwinian decision rules for altruism: Weighing cues for inclusive fitness as a function of the biological importance of the decision'. Journal of Personality and Social Psychology 67(5): 773-89. doi.org/10.1037/0022-3514.67.5.773 
Chisholm, James and Victoria Burbank. 1991. 'Monogamy and polygyny in southeast Arnhem Land: Male coercion and female choice'. Ethology and Sociobiology 12(4): 291-313. doi.org/10.1016/01623095(91)90022-I

Daly, Martin and Margo Wilson. 1982. 'Whom are newborn babies said to resemble'. Ethology and Sociobiology 3: 69-78. doi.org/10.1016/ 0162-3095(82)90002-4

-1983. Sex, Evolution and Behaviour, 2nd edition. Boston: Willard Grant Press.

Daly, Martin, Margo Wilson and Suzanne Weghorst. 1982. 'Male sexual jealousy'. Ethology and Sociobiology 3(1): 11-27. doi.org/10.1016/ 0162-3095(82)90027-9

D'Andrade, Roy. 1995. The Development of Cognitive Anthropology. Cambridge: Cambridge University Press. doi.org/10.1017/ CBO9781139166645

DeBruine, Lisa, Finlay Smith, Benedict Jones, S. Roberts, Marion Petrie and Tim Spector. 2009. 'Kin recognition signals in adult faces'. Vision Research 49(1): 38-43. doi.org/10.1016/j.visres.2008.09.025

Downey, Greg and Daniel Lende. 2012. 'Neuroanthropology and the encultured brain'. In The Encultured Brain: An Introduction to Neuroanthropology, edited by Daniel Lende and Greg Downey, 23-66. Cambridge, MA: MIT Press.

Goody, Esther. 1971. 'Forms of pro-parenthood: The sharing and substitution of parental roles'. In Kinship edited by Jack Goody, 331-62. Harmondsworth: Penguin.

Goody, Jack (ed.). 1971. Kinship. Harmondsworth: Penguin.

Hamilton, Annette. 1981. Nature and Nurture: Aboriginal Child-Rearing in North-Central Arnhem Land. Canberra: Australian Institute of Aboriginal Studies.

Hamilton, William. 1964a. 'Genetic evolution of social behaviour, I'. Journal of Theoretical Biology 7(1): 1-16. doi.org/10.1016/00225193(64)90038-4 
- $1964 \mathrm{~b}$. 'Genetic evolution of social behaviour, II'. Journal of Theoretical Biology 7(1): 17-52. doi.org/10.1016/0022-5193(64) 90039-6

Hammerstein, Peter (ed.). 2003. Genetic and Cultural Evolution of Cooperation. Cambridge, MA: MIT Press.

Heath, Jeffrey. 1982. Nunggubuyu Dictionary. Canberra: Australian Institute of Aboriginal Studies.

Ingold, Tim, David Riches and James Woodburn (eds). 1988. Hunters and Gatherers: Property, Power and Ideology, vol. 2. Oxford: Berg.

Lakoff, George and Mark Johnson. 1999. Philosophy in the Flesh: The Embodied Mind and its Challenge to Western Thought. New York: Basic Books.

Lende, Daniel and Greg Downey (eds). 2012. The Encultured Brain: An Introduction to Neuroanthropology. Cambridge, MA: MIT Press.

Lieberman, Debra, John Tooby and Leda Cosmides. 2007a. 'The architecture of human kin detection'. Nature 445 (February): 727-31. doi.org/10.1038/nature05510

—_. 2007b. 'The architecture of human kin detection: Supplementary information'. Nature 445 (February): 1-10. doi.org/10.1038/nature 05510

McKnight, David. 1986. 'Fighting in an Australian Aboriginal supercamp'. In The Anthropology of Violence, edited by David Riches, 137-63. Oxford: Basil Blackwell.

McMullen, Sue. 2014. "Growing up fast": The sexual and reproductive health of young women in a remote Aboriginal town'. PhD thesis. Charles Darwin University, Darwin.

Musharbash, Yasmine. 2016. 'Evening play: Acquainting toddlers with dangers and fear at Yuendumu'. In Social Learning and Innovation in Contemporary Hunter-Gatherers, edited by Hideaki Terashima and Barry Hewlett, 171-78. Tokyo: Springer. doi.org/10.1007/978-4431-55997-9_14 
Myers, Fred. 1986. Pintupi Country, Pintupi Self: Sentiment, Place, and Politics Among Western Desert Aborigines. Washington: Smithsonian Institution Press.

—. 1988. 'Burning the truck and holding the country: Property, time, and the negotiation of identity among Pintupi Aborigines'. In Hunters and Gatherers: Property, Power and Ideology, vol. 2, edited by Tim Ingold, David Riches and James Woodburn, 52-74. Oxford: Berg.

Nettle, Daniel, Rebecca Coyne and Agathe Colléony. 2012. 'No country for old men: Street use and social diet in urban Newcastle'. Human Nature 23(4): 375-85. doi.org/10.1007/s12110-012-9153-9

Park, Justin, Mark Schaller and Mark Van Vugt. 2008. 'Psychology of human kin recognition: Heuristic cues, erroneous inferences, and their implications'. Review of General Psychology 12(3): 215-35. doi.org/10.1037/1089-2680.12.3.215

Pinker, Steven. 2003. The Blank Slate: The Modern Denial of Human Nature. London: Penguin.

Porter, Richard. 1991. 'Mutual mother-infant recognition in humans'. In Kin Recognition, edited by Peter G. Hepper, 413-32. Cambridge: Cambridge University Press. doi.org/10.1017/CBO 9780511525414.016

Richerson, Peter and Robert Boyd. 2005. Not by Genes Alone: How Culture Transformed Human Evolution. Chicago: University of Chicago Press.

Sahlins, Marshall D. 1976. The Use and Abuse of Biology: An Anthropological Critique of Sociobiology. Ann Arbor, MI: The University of Michigan Press.

- 2013. What Kinship Is - And Is Not. Chicago: University of Chicago Press. doi.org/10.7208/chicago/9780226925134.001.0001

Scheffler, Harold W. 1978. Australian Kin Classification. Cambridge Studies in Social Anthropology No. 23. Cambridge: Cambridge University Press. doi.org/10.1017/CBO9780511557590

Schneider, David M. 1968. American Kinship: A Cultural Account. Englewood Cliffs, NJ: Prentice Hall. 
Shapiro, Warren. 1970. 'Local exogamy and the wife's mother in Aboriginal Australia'. In Australian Aboriginal Anthropology: Modern Studies in the Anthropology of the Australian Aborigines, edited by Ronald Berndt, 51-69. University of Western Australia, Perth: Australian Institute of Aboriginal Studies.

—_. 1979. Social Organization in Aboriginal Australia. New York: St. Martin's Press.

—_. 2005. 'Universal systems of kin categorization as primitivist projects'. Anthropological Forum 15(1): 45-59. doi.org/10.1080/ 0066467042000336706

—_. 2009. Partible Paternity and Anthropological Theory: The Construction of an Ethnographic Fantasy. New York: University Press of America.

—_. 2012. 'Extensionism and the nature of kinship: Comment'. Journal of the Royal Anthropological Institute (n.s.) 18(1): 191-93. doi.org/10.2307/41350814

Shore, Bradd. 1996. Culture in Mind: Cognition, Culture, and the Problem of Meaning. Oxford: Oxford University Press.

Silk, Joan. 1980. 'Adoption and kinship in Oceania'. American Anthropologist 82(4): 799-820. doi.org/10.1525/aa.1980.82.4.02a 00050

—_. 1990. 'Human adoption in evolutionary perspective'. Human Nature 1(1): 25-52. doi.org/10.1007/BF02692145

Smith, Eric. 2003. 'Human cooperation: Perspectives from behavioral ecology'. In Genetic and Cultural Evolution of Cooperation, edited by Peter Hammerstein, 429-44. Cambridge, MA: MIT Press.

Spiro, Melford E. 1993. "Is the western conception of the self "peculiar" within the context of the world cultures?' Ethos 21(2): 107-53. doi.org/10.1525/eth.1993.21.2.02a00010

Terashima, Hideaki and Barry Hewlett (eds). 2016. Social Learning and Innovation in Contemporary Hunter-Gatherers. Tokyo: Springer. doi.org/10.1007/978-4-431-55997-9

Tomasello, Michael. 1999. The Cultural Origins of Human Cognition. Cambridge, MA: Harvard University Press. 
Tomasello, Michael, Malinda Carpenter, Joseph Call, Tanya Behne and Henrike Moll. 2005. 'Understanding and sharing intentions: The origins of cultural cognition'. Behavioral and Brain Science 28(5): 675-735. doi.org/10.1017/S0140525X05000129

West, Stuart, Claire El Mouden and Andy Gardner. 2011. 'Sixteen common misconceptions about the evolution of cooperation in humans'. Evolution and Human Behaviour 32(4): 231-62. doi.org/ 10.1016/j.evolhumbehav.2010.08.001

White, N. and P. Parsons. 1973. 'Genetic and socio-cultural differentiation in the Aborigines of Arnhem Land, Australia'. American Journal of Physical Anthropology 38(1): 5-14. doi.org/10.1002/ajpa.1330380106 
This text is taken from Focality and Extension in Kinship: Essays in Memory of Harold W. Scheffler, edited by Warren Shapiro, published 2018 by ANU Press, The Australian National University, Canberra, Australia.

doi.org/10.22459/FEK.04.2018.06 